\title{
Developmental TVET Rhetoric In-Action: The White Paper for Post-School Education and Training in South Africa
}

\author{
Salim Akoojee \\ University of the Witwatersrand \\ eduVOC Education and Training \\ http://www.eduvoc.org.za \\ South Africa and Hong Kong \\ E-mail: salimakoojee@live.co.za
}

Received: 02 November 2015; Accepted: 10 January 2016; Published online: 30 April 2016

\begin{abstract}
This paper explores the extent to which latest developments in the Technical and Vocational Education and Training System in South Africa respond to key principles espoused for a developmental, democratic and inclusionary ideal. The White Paper for post school education and training (DHET, 2013) approved by Cabinet in November, 2013 is referred to by the Minister as the "definitive statement of the governments vision for the post school system" (DHET, 2013, p.4) and as such represents a crucial strategy document intended to chart the TVET direction to 2030. Using key theoretical constructs from development theory, this paper provides an assessment of the TVET strategy contained is the paper and explores the extent to which it does respond to the agenda defined by the promise. It is argued that the challenges outlined are not yet able to provide the blueprint for a TVET transformative vision. It is concluded that while the development rhetoric contained in the paper is plausible, the creative tinkering of the system is unlikely to lead to the radical revisioning necessary for a truly transformative TVET system. The underlying assumptions regarding purpose, impact and outcome will need to be carefully reconsidered if the system is to be responsive to the promises of the democratic developmental ideal to which the government is committed.
\end{abstract}

Keywords: TVET, Development State, South Africa, Further Education, Policy review, White paper, Vocational Education and Training

\section{Bibliographical notes:}

Dr Salim Akoojee is adjunct Associate Professor at the University of the Witwatersrand, Johannesburg. He is currently consultant in international education and training. His research includes education for and in developing contexts. 


\section{Introduction}

Education and Training is central to the establishment of the ideals of a democratic developmental state (Edigheji, 2010). It is argued that without a robust system that allows widespread access to sustainable livelihoods and productive work, the possibilities for achieving the national social development objectives considered necessary is unlikely to be realised. In this regard, the effective establishment of a vibrant, robust and effective Technical and Vocational Education and Training (TVET) is a sin qua non for an effective democratic developmental state (DDS) (Akoojee, 2010). National policy proposals in South Africa have reinforced the crucial role of education and training to economic development and provide the necessary rationale for radically revisioning, but the reality of implementing the proposals need some reconceptualization.

In this paper, I explore the current TVET policy development in South Africa identified in the latest White Paper ${ }^{1}$ on post school education and Training (DHET, 2013). The intention of the White Paper is to build an 'expanded, effective and integrated post-school education and training system', responsive to the needs of the myriad developmental challenges, the country faces. It is for that reason a necessary and laudable exercise to advance the interests of integration, expansion and effectiveness of the system. However, while the proposals suggest an awareness of the key elements necessary to achieve them, they are unlikely to lead to the realization of a coherent TVET system. Key elements of a responsive and inclusive developmentalism still need to be realized. It suggests that much has still to be done from a policy perspective to align with the priorities espoused, notwithstanding the myriad implementation challenges that have to be resolved.

The paper begins with an overview of the developmental ideal, the role of education and training more broadly in realizing this objective and then explores the envisaged role of the TVET system in its achievement. It then identifies key elements of the TVET system considered appropriate, for and in, a democratic developmental context. A consideration of key proposals identified in the latest White Paper then assessed for its developmental agenda.

\section{Towards an inclusive democratic developmentalism: The plausible rhetoric revisited!}

The concept of development has been dominated in academic discourse in the postcolonial era with the Rostow (1960) economic growth development trajectory still assuming some precedence, albeit in a new guise. In this view, the traditional path to development is associated with a quest for economic ascendency. In this perspective economic linearity and growth is expected to lead moving from 'traditional society' to one that is associated with 'high mass consumption'. This

1 White Papers are typically issued in Commonwealth countries. The process of legislation follows a route from Green to White paper. A Green Paper is a government document detailing the specifics of an issue and possible courses of action. It is usually the first step in undertaking a change in policy and/or enacting a major overhaul of some aspect of the government. In response to a green paper, governments issue a white paper detailing how the government is going to deal with the issue discussed in the green paper. The Green Paper for Post School Education and Training was released in January 2012, with the White Paper accepted by Cabinet in October 2013, and released in January 2014. 
staged notion of development has, however, been found wanting ${ }^{2}$. As a decidedly economist perspective, it is underscored by a view that suggests that any country could become part of the 'economic' elite by simply following the recipe. It is believed that by mimicking the advanced capitalist entities, the path from agrarian to industrial can easily be achieved. The Rostow Model (1960) becomes particularly resonant under human capital theories that assume that the transition to development can be achieved with the right blend of economic and social development elements. Of course, his mid- $20^{\text {th }}$ century modernization theory has given way to alternatives including 'new growth theory' (Lucas, 1988; Helpman, 2004) and 'institutional approaches' see for instance (Acemoglu \& Robinson, 2006; Hoff \& Stiglitz, 2001; Rodrik, Subramaniah, \& Trebbi, 2004)

Central to critiques of this model is the unquestioned relationship between development and the economy. The reality of the international changing and shrinking employment context see for instance (ILO, 2015) has not been factored, and neither the nature of the employment context in its increasing precariousness (Piketty, 2014). The rapid rise of transition economies, has also underscored the importance of different ways of thinking about development. In addition, assessments of the South-East Asian economic trajectories have unpacked the reality of the 'miracle' which has sometimes been considered less than humane and democratic in key geographic locations (Chang, 2010). The traditional development perspective has thus underplayed the inequalities that persist within, and between, nation states (Amin, 1997; McMichael, 2000; Wallerstein, 1998; Wallerstein, China and the World System since 1945, 2013; Wallerstein, 1979). Taken in tandem with current perspectives of the networked society (Castells \& Cardoso, 2005) the danger of this linearity simply enhancing and further alienating, become all the more real.

Democratic developmentalism is therefore, neither about the economy exclusively nor about the role that people play outside of their economic realm. Development has to take account of the rights of citizens to access key social benefits (Akoojee, 2010). Thandika Mkandawire (2010) reminds us that in the aftermath of the neoliberal heyday of Bretton Woods and the Washington Consensus era of the 1990s, "development is a deliberate and international process of economic transformation, as opposed to simply a result of the blind forces of the market" (Mkandawire, 2010, p. 60). Interestingly even this initial perspective essentially advanced by the Word Bank retreated from its initial assumptions regarding the uniformity of development. One report pointed out that,

"...there is no unique set of rules. Sustained growth depends on key functions that need to fulfilled over time [...]. We need to get away from formulae and the search for elusive 'best practises' and rely on deeper economic analysis to identify the binding constraints on growth" (World Bank, 2005, p.13).

Clearly the era of the 'one size fits all' recipe was not borne out by the evidence. A new developmental path needed to be found.

Thus, while development has important economic roots, there is need for widening its perspective to include social and political elements essential to human development. A more socially appropriate and inclusive model of development is

\footnotetext{
${ }^{2}$ Found wanting - a term referring to perceived inconsistencies/irregularities.
} 
one that both 'responsive' to a particular national context, while at the same time being inclusive to individuals and various social groups (Mukama, 2014).

Exploring the role of capabilities appears a more appropriate alternative as a developmental alternative. One that ensures that requires the state, on the one hand to "support the distribution of basic rights that gives individuals incentives to invest in their own capabilities" (Evans, 2010, p. 44), and on the other hand, it needs according to Amartya Sen "a program of skilful social support for health care, education and other relevant social arrangements' (Sen, 1999). In this regard, equity is both a means and an end to ensure the right balance for developmentalism. As Evans (2010) points out, the $21^{\text {st }}$ Century developmental state requires individuals 'capability expansion', which in the case of education is about ensuring appropriate and effective access to educational services, and the associated infrastructure that enables education to be effectively accessed, i.e. access to cheap transport systems (ibid, p.38). This notion has particular implications for TVET. It represents a starting point for thinking about how TVET systems need to be understood and its provisioning effectively implemented.

\section{TVET and inclusive development}

Technical and Vocational education and Training (TVET) has been ascribed a special role in development. As a recent report (UNESCO, 2015) pointed out:

Since education is the key to effective development strategies, technical and vocational educational and training (TVET) must be the master key that can alleviate poverty, promote peace, conserve the environment, improve the quality of life for all and help achieve sustainable development (Marope, Chakroun, \& Holmes, 2015, p. 13)

Despite the expansive roles ascribed to TVET in achieving the developmental ideal, its success is likely to be muted without the associated economic (and political) enabling circumstances that support its provisioning. Furthermore, the importance of skills for achieving sustainable livelihoods needs to be emphasized if it is to be responsive to developmental priorities (UNESCO, 2007). For TVET, therefore, the move away from traditional notions of development has to include re-defining purpose, function and ensures that effective institutional context is enhanced to achieve these.

With respect to purpose, the link between TVET and the economy has been a traditional focus of the sector. Described as a 'handmaiden of the economy', it has been considered the detritus of an industrial era (The Economist, 2014). The economic role ascribed is emphasised at the expense of the more substantive human development impacts which suggest that TVET and skills are essential for human capabilities (Sen, 2009) and the broader human rights perspective (Sayed, 2008). Clearly a more nuanced relationship between TVET and the economy is called for. Meanwhile the (formal) economy ${ }^{3}$ provides an important starting point

3 The notion of economies is proposed here, with the formal economy representing but one component of the entire spectrum of livelihoods development, Thus the notion not only of 'informal' economy needs to be considered but the reality of different types of economies which exist side by side embedded within communities as they relate to the complexities of the post-employment world, where there are simply no, or not enough formal sector jobs. See for instance (UNESCO, 2007) 
for its relevance. It is suggested that the sector needs to accord with the new economic reality in which it finds itself. One that re-defines responsiveness and reconfigures its relationship with the rights of its primary beneficiaries - and those most vulnerable to the changing economic context and most likely to be left behind as a result of its vagaries.

It has been proposed that the sector accords with a deliberative inclusive social justice perspective that seeks to redefine its traditional relationship with the economy. This does not mean that the interest of the economy is subverted, but that the role of the formal economy becomes a subset of wider societal perspectives. It requires the interest of people to come first, with the notion of communities and responsiveness replacing the economy as the primary category of responsiveness. Thus the much-touted perspective within TVET discourse that it was demanddriven needs reconsideration. In a context where the formal economy is nonemployment creating, it is perhaps useful to widen the definition of TVET as one UNESCO publication asserts:

TVET is a learning system in which both "soft" and "hard" skills are developed within a "joined-up", integrated development and delivery framework that seeks to improve livelihoods, promote inclusion into the world of work and that supports community and individual agency. (UNESCO, 2007, p. 2)

The definition provides an important starting point in responding to key features of the challenges to which TVET is charged. If we are to seriously review key features of the sector, much more attention needs to be given to purpose, function and role as it prepares the new generation of skilled citizens, with a new developmental purpose of responding to all, rather than a select few. This perspective suggests that 'people' will have to be prioritised over 'profits', and particularly over the whims and fancies of an imaginary, rather than real, economic order that is unlikely to provide the guaranteed employment to which it was once capable. This suggests a distinct change in role, function and purpose of TVET colleges which must be reconstituted to reflect this changing reality.

TVET has, therefore, to be responsive to the new order associated as it is with not inconsiderable youth unemployment and exclusion. The crisis is endemic as more and more people are left outside of the loop of the formal economy as the jobs crisis and the lack of employment opportunities deepens (Standing, 2011) and inequality becomes more endemic (Piketty, 2014; Oxfam, 2014).

\section{The South African developmental context}

South Africa is faced with challenges of poverty and inequity, with large-scale unemployment. Latest unemployment figures for instance currently estimate 5.5 million people to be unemployed and 14.8 million to be not economically active of an estimated working age population of 35.8 million $^{4}$ (Statistcs South Africa, 2015). In addition, data and reports suggest that the economy is largely non-

$4 \quad$ This is perhaps made more serious by reports about a more realistic expanded rate of unemployment of $36.1 \%$ (and 8.7 million unemployed), which is not accepted as officially. 
employment creating (Statistics South Africa, 2015; The Presidency, 2012) ${ }^{5}$.

It has been reported that key features of the system designed to serve as a catalyst for job creation are just not present. Spiralling inflation, looming downward international credit ratings and failing commodity prices together with current signs of a Chinese and Brazilian meltdown are not promising. The latest financial woes occasioned by the currency depreciation do not bode well. ${ }^{6}$ The economic fundamentals appear less robust than the situation in 2008, where the most deleterious effects of the international economic crisis was averted by a mix of prudent policy and large scale infrastructural state spending for the FIFA World Cup in 2010. The persistence of the electricity crisis and 'power supply' is steadily eroding any prospect of growth and further undermining an already faltering situation.

The current economic challenges have also been compounded by considerable and structural inequity - which allows some to be catapulted into the middle classes. This is not unique to the country as a recent Oxfam report $(2014)^{7}$ pointed out, but what is perhaps surprising is the quite alarming realisation that it has become manifestly more serious after the demise of Apartheid in 1994. This suggests deep structural disconnects which need to be addressed ${ }^{8}$.

There have a number of policy proposals to respond to the challenge. The common thread of developmental-ism is thus evident in a range of major policy proposals including the 'Reconstruction and Development Plan' (1994); the Growth, Employment and Redistribution (1996) (Akoojee and McGrath, 2004; National Development Plan, 2012) ${ }^{9}$. The latter for instance, argues for "a South African Democratic Developmental State (DDS) that will intervene to support and guide development so that benefits accrue across society (especially to the poor), and build consensus so that long-term national interest trumps short-term, sectional concerns" (The Presidency, 2012, p. 54). In response to developmental challenges

5 See for instance official report's the Department of Labour's 'The Job Opportunities and Unemployment - in the South African Labour market 2012-2013 Report.” Reports assessing the South African economy are also critical of the key economic fundamentals as reported in the economist indicators; see for instance, from http://www.economist.com/news/middle-east-and-africa/21578692-slow-growth-andsliding-currency-are-alarming-symptoms-deeper.

6 See for instance reports, e.g. http://www.fin24.com/Economy/sa-among-worsteconomic-performers-in-region-20160127?isapp=true.

7 The Oxfam report outlines the internationalization of inequity, "From Ghana to Germany, South Africa to Spain, the gap between rich and poor is rapidly increasing, and economic inequity has reached extreme levels, in South Africa, inequality is greater today than at the end of apartheid" (Oxfam, 2014, p.7).

8 The UNDPs Human Development Index, titled Work for Human Development (which incidentally crucially ignores the relationship between work and skills) arrives at similar conclusions regarding the lack of progress on the development front, with South Africa ranked at 118 th, with an HDI (0.66) with income inequity at 65 . (UNDP, 2015).

9 The National Plan, while endorsed at the highest level of government, has been criticized for not going far enough to resolve key challenges and has not been enthusiastically supported by all of the political partners, including the largest labour Union, the Congress of South African Trade Union (COSATU) and a key government partner, the Communist Party, who while allied to the dominant African National Congress has expressed serious reservations about its key features. Importantly, the current leader of the Communist Party is also the Minister of Higher Education. 
of unemployment and scarce skills, the National Development Plan (NDP) identifies education, training and skills development as one of the three "priorities" in the achievement of national objectives:

- Raising employment through faster economic growth;

- improving the quality of education, skills development and innovation;

- building the capability of the state to play a developmental transformative role (The Presidency, 2012, p. 27).

By ensuring that skills and education is placed on the national agenda, the possibilities for its renewal was secured at the highest level. It offers an opportunity for responding to the neglect of the sector. Importantly, by reinforcing the notion of a capable state with institutions established with enabling capacity to deliver human development and ensure equity, sustainability and peace. Therefore a capable state and developmental state in this context are two sides of the same coin: a developmental state, with its underpinning ideology, and a capable state, with an effective and efficient civil administration to redress unemployment, inequality and poverty. Importantly, there is an awareness that success will hinge on implementation, suggesting challenges in this respect as the plan asserts: "A plan is only as credible as its delivery mechanism is viable. There is a real risk that South Africa's developmental agenda could fail because the state is incapable of implementing it (The Presidency, 2012, p. 34).

\section{$5 \quad$ TVET and South Africa}

Education, training and skills deficits have been identified as intrinsic to the achievement of a democratic developmental state. The establishment in 2009 of the new ministry of post-school education and training, the Department of Higher Education and Training (DHET), saw increased attention to TVET. It signalled an opportunity to re-establish principles of equity enshrined in a form of democratic development state as a new political order was being established ${ }^{10}$. After its negligence was decided in the post-1994 era (Akoojee, 2012), the opportunity for its ascendency gained ground as the DHET saw an opportunity to respond to skills shortages, youth exclusion and the inverted pyramid of post-school provisioning which continued the skewed enrolment pattern of higher university enrolment ${ }^{11}$.The apartheid exclusion was perversely continued in a different form, this time with students choosing university over Further Education and Training (FET) colleges.

The White Paper of post-school education and training (DHET, 2013) is the latest policy proposal to chart the post-school education and training framework since the establishment of the Department of Higher Education and Training (DHET) in 2009. As the current policy framework, it is intended, as the title suggests to achieve an expanded, effective and integrated post-school system

102008 saw the establishment of a new political order, with the Presidency of Thabo Mbeki being nudged out of office and replaced by Jacob Zuma. The related transition promised a radical overhaul of the system, with new political structures being established and in the education sphere, the separation of schooling and the postschool system.

11 The unique exclusionary apartheid context undermined the right of black people to key technical skills (Akoojee, 2010). 
(DHET, 2013). Its developmental concern is clearly espoused by its intent to, "guide the DHET and the institutions for which it is responsible" and "to contribute to building a developmental state with a vibrant democracy and a flourishing economy" (DHET, 2013, p. 4; emphasis inserted).

The recognition of colleges as a key component of the post-school education and training and will be given considerable attention has to be commended: The White paper asserts that they are "central to the provision of post-school education and training" as well as it "is the area targeted by the DHET for the greatest expansion and diversification" (DHET, 2013, p. 11). It therefore represents an undeniable critical feature of the envisaged future post-school education and training landscape. The reference to the College System includes inter alia what are to be referred to as TVET Colleges ${ }^{12}$ and former Adult literacy centres now called Community Colleges ${ }^{13}$. While TVET colleges emerged from former FET colleges, full-time post-school vocational colleges offering technical training to post school youth, community college are essentially a new entity emerging from the former Public Adult Learning Centres (PALCs) and Adult Education Centres (AETs), offer school-level literacy and exit qualifications for adults.

As a central element in the revitalisation of the post-school sector, TVET's proposed role is a key element of the post-school education and training system. Issues related to function and purpose, expansion and diversification are therefore crucially significant if the system is to achieve its developmental purpose.

\subsection{TVET Colleges (former FET Colleges)}

TVET Colleges emerge from the 50 public formed as a result of the merger of the 154 former Technical Colleges after rationalization in 2001 (Government of South Africa, 1998).They were designed to respond to the skills needs of the formal economy as a key component of mid-level post-school skills provisioning. Provision in the sector is uneven, with the post-Apartheid government continuing the cycle of neglect that preceded it. Accounts of the effectiveness of colleges are less than complimentary. The National Development Plan highlighted the reality that the sector was "not effective", "too small" and lamented that the "output quality (was) poor" (The Presidency, 2012, p. 50). Other policy documents have also referred to weak financial management, teacher ineffectiveness, poor administration and governance, inadequate infrastructure, poor labour market outcomes and inadequate responsiveness to needs of students (DHET, 2012b; Akoojee, 2008).

The range of interventions designed to improve provisioning, includes recapitalization (a once-off funding injection) in 2005, curriculum renewal in the National Curriculum (Vocational) (NCV) and various legislative interventions in the form of the Further Education and Training (FET) Acts of 2006 and 2012 (RSA,

12 The term TVET Colleges which replaced Further Education and Training (FET) is, nonetheless, more symbolic than it is substantive since it is considered to simply "better reflect their nature and better define their main role in the 'diversified' postschool system." (ibid, p.12).

13 Other components of the college system include those not under direct DHET responsibility Other colleges (responsibilities of other ministries) and private colleges (business entities), together with the South African Institute for Vocational and Continuing Education and Training (SAIVCET) which is expected to respond to overall quality of college programmes (DHET, 2013, p. 26), are not included in this paper. 
2006) (RSA, 2012) ${ }^{14}$. The key governance changes in 2012 reversed the decentralisation from provincial to the national Department of Higher Education and Training (DHET), resulting in the current e-amalgamation of staff into government service. Despite the restructuring and funding enhancements ${ }^{15}$, the sector does not have a positive image both in terms of quality, outcomes, programme relevance or governance and administration (Akoojee, 2010; DHET, 2012a; DHET, 2012b). The latest intervention, referred to the 'turnaround strategy' intends to lay the basis for administrative and management renovation and restore effective functionality (DHET, 2012a). The real challenges, of course, are less technical than they are substantive if the developmental perspective is to be advanced. Two substantive issues are considered, first purpose of these TVET Colleges and second, expansion and diversification, which suggest an important basis for TVETs developmental outcomes.

\subsubsection{Labour Market Purpose}

The White paper refers to a range of profound purposes for the post-school system. The bold commitment of the relationship between education and the labour market from the Minister in the 'Forward' of the White Paper reminds the reader about the bold purposes to which post-school education is to be directed:

"...the education and training system should not only provide knowledge and skills required by the economy. It should also contribute to developing thinking citizens, who can function effectively, creatively and ethically as part of a democratic society. They should have an understanding of their society, and be able to participate fully in its political, social and cultural life" (DHET, 2013, p. 8).

This policy intention to expand the remit of college system to cater for creativity and a thinking citizenry responsive to democratic, ethical and participatory civic responsibility is not, however, carried through in the context of the college system. References to purpose of the college system are replete with responsiveness to the formal economy as its primary imperative:

"....since the main purpose of the TVET colleges is to prepare students for the workplace and/or self-employment, it is essential that they develop and maintain close working relationships with employers in their areas of study" (DHET, 2013, p. 16, author emphasis).

14 The 2012 FET Act essentially reverses the decentralization of the 2006 Act, "To amend the Further Education and Training Colleges Act, 2006, so as to remove all references to provincial authority; to assign functions previously assigned to the Member of the Executive Council to the Minister; to remove all references to 'Head of Department' and replace them with 'Director-General'; to regulate the conduct of members of the council, members of a committee of the council and staff of a public further education and training college engaging in business with the relevant public college; to provide afresh for the appointment of staff..." (RSA, 2012, p. 2).

15 Government funding has also increased but not as exponentially as student enrolment. The sector received R780million in 1998 ( $1.7 \%$ of national education budget), which increased to R4.95 billion in 2012 (2.4\% of national education budget) (DHET, 2012a and 2013). 
Unfortunately references to workplaces, employers and self-employment assume that employment opportunities are available and possibilities for self-employment are easily attained. Elsewhere, the reference to close partnerships between colleges and employers suggests that partnerships will automatically create vast numbers of opportunities. Colleges are expected to be assisted to "...locate opportunities for work-integrated learning and help them to place students when they complete their qualifications" (ibid). In addition it is also pointed out that the TVET system has to respond meaningfully to the main challenge faced by many nations identified as, "...too few young people and adults are currently able to develop the skills, knowledge and attitudes they need for today's changing world of work". Thus while the initial commitment to a widened notion of TVET purpose, the reality is that the discourse resonates with a narrowly economic and productivist approach to TVET (Anderson, 2009), which is done at the expense of the social and equity components. Of course, the assumption that the formal labour market will simply absorb these graduates is not considered. The purpose is justified by reference to an international source (UNESCO, 2012) which identified challenges with a lack of responsiveness to the economy. ${ }^{16}$

By focusing on the formal economy, not only do non-economic factors get relegated to the periphery, but the range of economic possibilities outside of the formal economic sector becomes stymied. Thus a golden opportunity is missed by ignoring what is potentially a critical component of the developmental context informal or non-formal sectors, likely to the ones most 'developmental'. Thus the ambitious aims espoused in the initial pages of the White Paper are not carried through in the text.

\subsubsection{Expansion}

The White Paper focusses on expanding the post-school education and training system, under the broad notion of access, the massification of the system is considered a priority. Both the context and the content of the expansion are however, less than appropriate to purpose. First, the colleges are expected to advance access by providing opportunities to post-school youth exclusively, and second, access is understood in ways that focus on numbers rather than substance and quality. While expanding youth opportunities is clearly necessary given the large numbers of NEETs ${ }^{17}$, but restricting the remit of these institutions to a postschool youth alone is short-sighted given the demand by the sheer extent of the vulnerable youth and adults outside of the system - many who have not had the opportunity of formal education and require skills development and vocational alternatives.

The White Paper (DHET, 2013) aims to expand headcount enrolment at colleges from, "just over 345000 in 2010 to an estimated 650000 in $2013 \ldots$ (reaching) one million by 2015 and 2.5 million by 2030" (DHET, 2013, p. 7). The identification of these quantitative targets is at the same time both distressing as it is laudable. While it places much-needed attention on the TVET sector in the post-

16 That report warned systems to link colleges with the economy, warning against systems that were "poorly articulated with labour market demands (were) not contributing towards socio-economic development needs as much as expected" (UNESCO, 2012, p. 5).

17 See for instance a comprehensive assessment of the extent of the problem (Cloete, 2009). 
school education and training system and is potentially able to allow it to take its rightful place within it. If the quality challenges are not also given attention, systemic challenges identified above are not only likely to continue, but is likely to lead to a bad system potentially become worse. There is a need to ensure that fundamentals in the system are in place for the expansion to have any positive effect. Thus issues related to teacher quality, infrastructure and relevance to labour markets (formal and informal) need to be firmly put in place before the envisaged expansion. Thus, while expansion is laudable for its intent, it is clearly problematic given the current state of the TVET Colleges. For it to be truly effective, developmental and enable transformation of the sector and country, TVET access has to enhance system credibility and enable responsiveness to the various developmental challenges faced. Thus access has to go beyond simply expanding youth enrolment and enable outcomes that are appropriate. It has to take account quality criteria at every level of its implementation. This requires the traditional notion of access to be reconceptualised to include imperatives that to go beyond expansion.

Notions of diversification are also understood in a manner that is likely to lead to further inequity on the system. In response to the challenge of 'uneven' quality, a form of institutional diversification is envisaged that has potential to further exacerbate differences between the more effective and less functional colleges. The suggestion is those less 'functional' become more 'effective', with those more effective supported to become excellent (DHET, 2013, p. 12). The fact that excellence is not the overall purpose of all, with differential notions of the term advanced for different contexts is, perhaps, lamentable.

\subsection{Community Colleges}

Community Colleges represent a critical feature of the College system. They are expected to resolve the missing link both in terms of purpose and learner cohort. Described as institutions that offer programmes not catered for by the current public education and training institutions, the range of options could be considered essential to the needs of, and for, a developmental context. Programmes that these colleges ae expected to deliver include:

“...community health care, parenting and childcare, early childhood development, care for the aged,, care for those with HIV/AIDS and other diseases, citizenship education, community organization, making effective use of new community technologies for various purposes such as seeking information or marketing local products, skills for self-employment in a range of areas, from market gardening to small-scale manufacturing, arts and crafts" (DHET, 2013, p. 20).

Their developmental imperative is reinforced by the responsiveness to their immediate locality and context, as they are "expected to be sensitive to the needs of their communities" (ibid, p. 21) ${ }^{18}$.

The diverse range of learner cohort to which Community Colleges are expected to respond are described as comprising those not catered for elsewhere (TVET

18 Also, in the same document, it is reiterated that they "will be geared to the needs and desires of local communities and their organization including community-based cooperatives and businesses" (ibid, p. 22). 
colleges and Universities). Those learners who, "have not completed school (and) need a second chance to do so" as well as others "(who) may have lost their jobs or were made redundant by new technologies and seek to re-skill themselves" (DHET, 2013, p. 13). Significantly, there is a realization that these colleges need to provide opportunities that take account of the current economic context:

"We should also face the fact that, given the current high levels of unemployment, (those made redundant) may have little chance of entering the formal labour market as employees and need to find alternative ways to sustainable livelihoods' (DHET, 2013, p. 20).

They resolve the problem of alternative education and training structures for those not catered for elsewhere - a diverse range of learner cohorts that are likely to be most affected by the current South African labour market inconsistencies. The colleges are expected to, "find ways to cater to the needs of the millions of adults and youth who are unemployed, poorly educated and not studying" and for which the university and college system will not be sufficient (DHET, 2014, p. 13). The 3200 centres serving 265000 learners (in 2011) are expected to reach a million by 2030 (DHET, 2013, p. 21).

The biggest challenge from a developmental perspective is that the current structure that these institutions are expected to amalgamate with, are by all accounts unlikely to either be speedily be established or reconstituted based on their current structure. They are constituted loosely as Public Adult Learning Centres (PALCs), formerly referred to as Adult Education and Training Centres (AETs). In these institutions, classes are run on part-time and after school hours, with many teachers employed as part-time contract workers without tenure. They essentially serve as adult literacy centres, offering General Education and Training Certificates (GETCs) and Senior Certificate (school-leaving certificate) programmes. Under provincial control, attention to them was minimal and quality and impact likely to have been less than acceptable. They are described in the White paper as institutions, "whose efforts have been inadequate" (ibid, 2013, p. 21).

These diverse, disparate set of institutions loosely responding to adult literacy (schooling) are neither geared for, nor are coherently organized, to take on this crucial skills development function. Even the White Paper admits their inability as institutions to attract adults and youth interested in gaining labour-market and sustainable livelihood skills, and those interested in learning for general selfimprovement or cultural and community development" (DHET: 2013, p.21).

As critical structures, their effectiveness to fulfil effectively their mandate is likely to be limited, given their background, their lack of experience with vocational programmes, the lack of experience on community responsiveness and general lack of a coherent institutional attention in the former departments. Relegating the most critical element of the developmental paradigm to a new structure which by all accounts is inadequate appears nothing less than bizarre.

\section{Conclusion}

It is contended that the South African notion of developmentalism as reflected in the TVET policy context has in fact been derived from a traditional notion of economic development, based on a perspective that promises jobs on the basis of skills developed. The White Paper's contribution to the TVET sector is likely to be 
less than effective in resolving the key contradictions of purpose, expansion and diversity.

The view that the TVET colleges sector should be responsive to the formal labour market is clearly problematic, not the least because it is expected to respond to a non-job-creating formal labour market designed for those certificated youth that emerge from the schooling system. The opportunity has been lost for establishing these colleges as fully functional skills development entities responsive to a range of needs in, and for, a developing South African context. Instead, by relegating the real skills development needs of the country to a structure still to be established, with questionable institutional bona fides is less than ingenious. It does appear that the White Paper, by focusing on numbers and expansion has ignored the current context in which TVET colleges find themselves - whether it is in terms of governance, curriculum, teaching/learning deficits and resourcing.

Indeed, the need to enable TVET colleges to undertake real skills development to community needs appears to be undermined by a blind commitment to expanding enrolment at the expense of quality. In addition, notions of college transformation need to include diversifying learner cohorts, programmes, different learning forms (distance and blended, responding to different learner needs with flexible tuition times and forms of learning. Need to be inclusive and include all forms of vocational learner, from employed, unemployed to schooled and certificated, to uncertificated. The proposal to separate the post-school learners from the other TVET sectors, while underpinned by principles of diversity tends to isolate the different sectors to which colleges should be responsive.

The reality of South Africa's high unemployment, skill needs and shortages suggests that a radical thinking for colleges is called for - one which takes communities as a starting point, rather than the end. It does seem that the jury is out, while the rhetoric is plausible, the creative tinkering has not resulted in radical revisioning of the sector for the benefit of all. 


\section{References}

Acemoglu, D., \& Robinson, J. (2006). Economic origins of dictatorship and democracy. Cambridge: Cambridge University Press.

Akoojee, S. (2008). FET college lecturers: the 'devolving' link in the South African skills development equation. Journal of Vocational Education and Training (JVET), 60(3), 297-313.

Akoojee, S. (2010). Intermediate skills development in South Africa: Understanding the context - responding to the challenge!. In O. Edigheji (Ed.), Constructing a Democratic Developmental State in South Africa: Potentials and challenges (pp. 261-282). Cape Town: HSRC Press.

Akoojee, S. (2012). Recession, Skills and National Development: The South African case. In K. Farmer (Ed.), Financial Crises: Causes, Management, and Economic Impacts (pp. 171-185). Frankfurt/New York: Nova Science Publishers.

Amin, S. (1997). Capitalism in the Age of Globalization. London: Zed Press.

Anderson, D. (2009). TVET and Ecologism: Charting new terrain. In J. Fien, R. Maclean, \& P. Man-Gon (Eds.), Work, Learning and Sustainable Development (pp. 35-58). Dordrecht: Springer.

Chang, H. (2010). How to 'do' a developmental state: political, organizational, and human resource requirements for the developmental state. In O. Edigheji (Ed.), Constructing a Democratic Developmental State in South Africa: Potentials and Challenges (pp. 82-96). Cape Town: HSRC Press.

Cloete, N. (2009). Responding to the educational needs of post-school youth: Determining the scope of the problem and developing a capacity-building model. Cape Town: CHET.

DHET (2012a). Further Education and Training Colleges. Turnaround Strategy. Pretoria: Department of Higher Education and Training.

DHET (2012b). Green Paper for Post-School Education and Training. Pretoria: Department of Higher Education and Training (DHET).

DHET (2013). White Paper for Post-School Education and Training: Building an expanded, effective and integrated education and Training system. Pretoria: Department of Higher Education and Training.

Edigheji, O. (2010). Constructing a democratic developmental state in South Africa: Potentials and challenges. In O. Edigheji (Ed.), Constructing a democratic developmental state in South Africa: Potentials and challenges (pp. 1-36). Cape Town: HSRC Press.

Evans, O. (2010). Constructing the 21ts century Developmena state: Potentialities and Pitfalls. In O. Edigheji (Ed.), Constructing a democratic developmental state in South Africa (pp. 37-58). Cape Town: HSRC Press.

Helpman, E. (2004). The mystery of economic growth. Cambridge: Harvard University Press.

Hoff, K., \& Stiglitz, J. (2001). Modern economic theory and development. In J. Meier, \& J. Stiglitz (Eds.), Frontiers of development economics (pp. 389-487). New York: Oxford University Press.

ILO (2015). Global Employment Trends for Youth: Scaling up investments in decent jobs for youth. Geneva: International Labour Office.

Lucas, R. (1988). On the mechanics of economic development. Journal of Monetary Economics 22, 3-42.

Marope, P., Chakroun , B., \& Holmes, K. (2015). Unleashing the Potential: 
Transforming Technical and Vocational Education and Training. Paris: UNESCO.

McMichael, P. (2000). (2000) Development and Social Change: A Global Perspective. Thousand Oaks, CA: Pine Forge Press.

Mkandawire, T. (2010). From maladjusted states to democratic developmental states in Africa. In O. Edigheji (Ed.), Constructing a democratic develomental state in South Africa (pp. 59-81). Cape Town: HSRC Press.

Oxfam (2014). Even it up: Time to end extreme Inequality. Oxford: Oxfam International.

Piketty, T. (2014). Capital in the Twenty-First Century. Cambridge and London: Harvard University Press.

Rodrik, D., Subramaniah, A., \& Trebbi, F. (2004). Institutions rule: The primacy of institutions over geography and integration in economic development. Journal of Economic Growth 9(2), 131-165.

Rostow, W. (1960). The Stages of Economic Growth: A Non-Communist Manifesto. Cambridge: Cambridge University Press.

RSA (2006). Further Education and Training Colleges Act (Act 16 of 2006). Pretoria: Government Printer.

RSA (2012). FET Colleges Amendment Act, 2012 (Act No. 3 of 2012). Pretoria: Government Printer.

Sayed, Y. (2008). Education and poverty reduction - eradication: Omissions, Fashions and Promises. In S. Maile, Education and Poverty Reduction Strategies: Issues of coherence (pp. 53-67). Pretoria: HSRC Press.

Sen, A. (1999). Development as freedom. New York: Knopf.

Sen, A. (2009). The idea of Justice. Cambridge: Harvard University Press.

Standing, G. (2011). The Precariat: The New Dangerous Class. London and New York: Bloomsbury Academic.

Statistcs South Africa (2015). Quarterly Labour Firce Survey. Pretoria: StatsSA.

The Economist (2014). Retooling Vocational Education. The Economist, http://www.economist.com/news/business/21613279-retooling-vocationaleducation-got-skills.

The Presidency (2012). National Development Plan 2030 : Our Future-Make it work. Pretoria: National Planning Commission (NPC).

UNDP (2015). Human Developent Report: Work for Human Development. New York: UNDP.

UNESCO (2007). Education for Livelihoods and Civic Participation in PostConflict Countries: Conceptualizing a holistic approach to TVET Planning in sub-Saharan Africa . Bonn: UNESCO.

UNESCO (2012). Current Issues and Trends in Technical and Vocational Education and Training. Paris: UNESCO.

Wallerstein, E. (1979). The Capitalist World Economy. Cambridge: Cambridge University Press.

Wallerstein, E. (1998). Utopistics: Or, Historical Choices of the Twenty-First Century. New York: The New Press.

Wallerstein, I. (2013). China and the World System since 1945. Retrieved from Youtube: https://www.youtube.com/watch?v=uQV0w11vVO8.

World Bank (2005). Economic growth in the 1990s: Learning from a decade of reform. Washington: World Bank. 